\title{
Antibody-induced Desensitization of the Insulin Receptor
}

\author{
STUDIES OF THE MECHANISM OF DESENSITIZATION IN
}

3T3-L1 FATTY FIBROBLASTS

\author{
Carl Grunfeld, Emmanuel Van Obberghen, F. Anders Karlsson, and \\ C. RoNald KaHN, Diabetes Branch, National Institute of Arthritis, \\ Metabolism and Digestive Diseases, National Institutes of Health, \\ Bethesda, Maryland 2020.5
}

A B S T R A C T Antibodies against the insulin receptor (Anti-R), which are found in the serum of type B patients with the syndrome of insulin resistance and acanthosis nigricans, inhibit the binding of insulin to its receptor and mimic the actions of insulin when studied acutely in vitro. After prolonged exposure of 3T3-Ll cells to Anti-R, the insulinomimetic activity is lost, and the cells show a marked decrease in their maximal response to insulin (antibody-induced desensitization), thus providing a model for the insulin resistance seen in vivo. This study explores in detail the mechanism and specificity of desensitization in 3T3-Ll cells.

Desensitization, like the insulinomimetic activity of Anti-R, requires bivalence. Monovalent preparations of Anti- $R$ inhibit insulin binding and shift the insulin biological dose-response curve to the right, but do not decrease the maximal insulin response. The affinity of monovalent Anti- $R$ is less than that of the native antibody. Cross-linking of monovalent Anti- $\mathrm{R}$ reconstitutes its insulinomimetic activity and partially reconstitutes desensitization.

Desensitized cells are resistant to the insulinomimetic actions of concanavalin $\mathrm{A}$, which interacts with the insulin receptor, but are not desensitized to spermine and vitamin $K_{5}$, insulinomimetic agents that

This work was presented in part at the 61st Annual Meeting of the Endocrine Society, Anaheim, California, 13-15 June 1979. Abstract 3.

Dr. Karlsson is a Visiting Associate on leave from the Department of Internal Medicine, University Hospital, Uppsala, Sweden. Address reprint requests to Dr. C. Grunfeld, University of California Service, Veterans Administration Medical Center (IIIF), San Francisco, California 94121. Dr. Van Obberghen's current address is Department of Experimental Medicine, Groupe INSERM, Faculty of Medicine (Pasteur), 06034 Nice, Cedex, France.

Received for publication 28 January 1980 and in revised form 1 July 1.980. are thought to act independently of the insulin receptor. Glucose, pyruvate, or certain hexoses are required in the incubation media for desensitization to occur. Although Anti-R is taken up into cells and degraded by lysosomes, chloroquine, cycloheximide, colchicine, and cytochalasin $E$ have little influence on the induction of or recovery from antibody-induced desensitization. These data suggest that desensitization is not merely due to the inhibition of insulin binding, but is a complex process involving a decreased ability of the receptor to generate a biological response.

\section{INTRODUCTION}

Antibodies directed against the insulin receptor have been found in the plasma of a group of patients with a syndrome characterized by severe insulin-resistant diabetes, acanthosis nigricans, and a marked reduction in the binding of insulin to circulating monocytes $(1,2)$. The antibodies reproduce this latter defect in vitro, inhibiting the binding of insulin to its receptor on normal monocytes and cultured cells $(2,3)$.

The mechanism by which these antibodies produce insulin resistance has been difficult to explain. Exposure of some cells to hormones, such as insulin $(4,5)$, results in a decrease in receptor number. Antibodies against the acetylcholine receptors are known to accelerate receptor degradation (6). However, this does not appear to be the mechanism by which antibodies against the insulin receptor cause insulin resistance, as the binding defect on the patients' cells can be reversed by a mild acid wash capable of dissociating antibody-antigen complexes (7).

Further, in contrast to the insulin resistance seen in these patients, the antibodies mimic rather than block the effects of insulin when studied in vitro. Thus, in adipocytes and skeletal muscle they stimulate glucose and amino acid transport, glucose metabolism to $\mathrm{CO}_{2}$, 
and glucose incorporation into lipid and glycogen (8-11). They also inhibit lipolysis and mimic insulin's effects on the enzymatic activity of glycogen synthase, phosphorylase, and lipoprotein lipase (10-13).

3T3-Ll cells are an established mouse cell line (14, 15) that possess most of the characteristics of adipocytes and have been used extensively for the study of insulin receptors and insulin responsiveness (16-21). Recently, we have used 3T3-Ll cells to develop an in vitro model for the insulin resistance seen in patients with antibodies against the insulin receptor (22). As with other cells, these antibodies rapidly inhibit the binding of insulin and mimic the action of insulin in 3T3-Ll cells. However, prolonged exposure of the cells to antibody results in loss of the antibody's insulinomimetic activity and the development of insulin resistance, without further changes in insulin binding. We have called this process antibody-induced desensitization.

In the present study we explore in more detail the induction of and recovery from antibody-induced desensitization. Data suggest that the insulin resistance in patients with antibodies against the insulin receptor is a complex process that is not merely due to the inhibition of insulin binding, but that also involves postreceptor alterations.

\section{METHODS}

Materials. Cycloheximide, chloroquine, colchicine, 2deoxyglucose, pyruvate, glucosamine, galactose, mannose, 3-O-methylglucose, glucose, cysteine, and Hepes were purchased from Sigma Chemical Co., St. Louis, Mo. Cytochalasin $E$ and 1-methyl-3-isobutylxanthine were purchased from Aldrich Chemical Co., Inc., Milwaukee, Wisc., bovine serum albumin (BSA), ${ }^{1}$ from Armour Pharmaceutical Co., Chicago, Ill.; pork insulin, from Elanco Products Co., Indianapolis, Ind., papain, from Worthington Biochemical Corp., Freehold, N. J., Sephadex G-200 and Protein A-Sepharose, from Pharmacia Fine Chemicals, Piscataway, N. J.; and hyamine, from Packard Instrument Co., Inc., Downers Grove, Ill.

$\left[{ }^{14} \mathrm{C}\right]$ Glucose $(1 \mathrm{mCi} / \mathrm{mmol}) \quad 2-,\left[{ }^{14} \mathrm{C}\right]$ deoxyglucose $(54.4$ $\mathrm{mCi} / \mathrm{mmol}),{ }^{3} \mathrm{H}$-labeled amino acid mixture $(5 \mathrm{mCi} / \mathrm{mmol})$, and carrier-free [ $\left.{ }^{125} \mathrm{I}\right] \mathrm{NaI}$ were purchased from New England Nuclear, Boston, Mass. Petri plates were obtained from Falcon Labware, Div. of Becton-Dickinson \& Co., Oxnard, Calif. Linbro FB-6-TC multi-well plates and fetal calf serum were obtained from Flow Laboratories, Inc., Rockville, Md.

Guinea pig anti-human $\mathrm{Fab}$ was generously provided by Dr. Warren Strober, National Institutes of Health.

Cell culture. 3T3-L1 cells isolated by Howard Green of the Massachusetts Institute of Technology were generously provided to us by him and Dr. Ora M. Rosen of the Albert Einstein College of Medicine. Cells were grown and differentiated as previously described (21). In brief, cells were plated at a density of $1-4 \times 10^{3}$ cells $/ \mathrm{cm}^{2}$ and fed every other

\footnotetext{
${ }^{1}$ Abbreviations used in this paper: Anti-R, antibody against the insulin receptor; Anti-R Fab, monovalent Fab preparation of Anti-R; BSA, bovine serum albumin; KRP, Krebs-Ringer phosphate buffer, $\mathrm{pH} 7.4$, containing bovine serum albumin $(20 \mathrm{mg} / \mathrm{ml})$ and $1.3 \mathrm{mM} \mathrm{CaCl}$.
}

day with Dulbecco-Vogt Modified Eagle's Medium containing $10 \%$ fetal calf serum. Cells were kept in a humidified atmosphere of $5 \% \mathrm{CO}_{2}$ and $95 \%$ air at $37^{\circ} \mathrm{C}$. Differentiation was enhanced by treating confluent cells for $2 \mathrm{~d}$ with standard medium supplemented with $0.5 \mathrm{mM} 1$-methyl-3-isobutylxanthine and $1 \mu \mathrm{g} / \mathrm{ml}$ insulin followed by $4 \mathrm{~d}$ in medium supplemented by insulin alone. Cells were then refed with standard medium and used within 3-8 d. The properties and hormonal responsiveness of cells prepared in this manner have been described (21). Glucose-free media were prepared by the National Institutes of Health media unit. Fetal calf serum for glucose-free experiments was dialyzed four times against 10 vol of Dulbecco's phosphate-buffered saline.

Preparation of suspended cells. Suspended cells were prepared by incubation of plates in Joklik's spinner medium supplemented with $2 \mathrm{mM}$ EDTA for $30 \mathrm{~min}$ at $37^{\circ} \mathrm{C}(22)$. The cells were washed once in Joklik's spinner medium with $2 \mathrm{mM}$ EDTA and then washed twice in an incubation medium appropriate for the studies to follow. Cell numbers were determined using a hemocytometer.

Preparation of antireceptor antibodies. Partially purified antibody against the insulin receptor (Anti-R) was prepared by precipitation with $33 \%$ ammonium sulfate of the plasma from a patient (B-2) with insulin resistance of the type B syndrome $(1,22)$. The precipitate was dissolved in $0.05 \mathrm{M}$ sodium phosphate buffer at $\mathrm{pH} 7.4$ in $0.15 \mathrm{M} \mathrm{NaCl}$ and dialyzed against that buffer to an IgG concentration similar to that of the original plasma (22).

${ }_{125}^{12}$ I-Anti-R was prepared by the method of Jarrett et al. (23). Anti-R was further purified by chromatography on DEAEcellulose in $0.01 \mathrm{M}$ potassium phosphate buffer, $\mathrm{pH} 8.0$, and iodinated by modification of the chloramine $T$ method (24) to a specific activity of $14-15 \mathrm{mCi} / \mathrm{mg}$, or the equivalent of 1 iodine/IgG molecule. A population of antibodies enriched for Anti-R was prepared by selective cytoadsorption and subsequent elution from IM-9 lymphocytes, a cell rich in insulin receptors (23). Unlabeled insulin competed for $>75 \%$ of the ${ }^{125}$ I-Anti-R prepared in this manner (23).

Monovalent Anti-R (Anti-R Fab) was prepared by papain cleavage (25). Anti-R was chromatographed over a G-200 Sephadex column equilibrated in $0.1 \mathrm{M}$ phosphate buffer and then digested for $10 \mathrm{~h}$ at $37^{\circ} \mathrm{C}$ in a solution containing $0.3 \mathrm{mg} / \mathrm{ml}$ papain, $1 \mathrm{mM}$ EDTA, and $4 \mathrm{mM}$ cysteine. The reaction was terminated by chilling to $4^{\circ} \mathrm{C}$ and adding iodoacetamide (final concentration, $5 \mathrm{mM}$ ). The reaction mixture was passed over a column of Protein A-Sepharose to remove intact immunoglobulins and Fc components. The Fab fraction was further purified by chromatography on Sephadex G-200.

${ }_{125}$ I-Insulin binding. ${ }^{125}$ I-insulin was prepared by modification of the chloramine T method (24) to specific activities of $140-180 \mu \mathrm{Ci} / \mathrm{mg}(0.4-0.5 \mathrm{I} /$ insulin molecule equivalent). Insulin binding to suspended cells was measured as previously described $(21)$ by incubating cells $\left(1-5 \times 10^{6}\right.$ cells $\left./ \mathrm{ml}\right)$ for $90 \mathrm{~min}$ at $15^{\circ} \mathrm{C}$ in Hepes buffer ( $\mathrm{pH} 8.0$ ) containing $20 \mathrm{mg} / \mathrm{ml}$ BSA together with ${ }^{125} \mathrm{I}$-insulin $(0.2 \mathrm{ng} / \mathrm{ml})$ alone or with varying concentrations of unlabeled insulin. The amount of ${ }^{125}$ I-insulin bound was determined after centrifugation in a Beckman Microfuge (Beckman Instruments Inc., Spinco Div., Palo Alto, Calif.) for $1 \mathrm{~min}$. Nonspecific binding, the amount of tracer bound in the presence of $10 \mu \mathrm{g} / \mathrm{ml}$ unlabeled insulin, was subtracted from total binding.

Insulin binding to cells adherent to the plates was determined using the same conditions as above, except that the incubation was done for $120 \mathrm{~min}$ and was terminated by three 3-ml washes with Dulbecco's phosphate-buffered saline at $4^{\circ} \mathrm{C}(21,22)$.

Glucose oxidation. Glucose oxidation (21) was assayed using suspended cells incubated at $37^{\circ} \mathrm{C}$ for 1 or $2 \mathrm{~h}$ in 
Krebs-Ringer bicarbonate buffer ( $\mathrm{pH} 7.4$ ) containing $20 \mathrm{mg} / \mathrm{ml}$ BSA supplemented with $0.3 \mathrm{mM}\left[\mathrm{U}-{ }^{14} \mathrm{C}\right]$ glucose $\left(2 \times 10^{5}\right.$ $\mathrm{cpm} / \mathrm{ml})$. The amount of ${ }^{14} \mathrm{CO}_{2}$ formed was measured by trapping in hyamine.

Deoxyglucose transport. 2-Deoxyglucose transport (22) was assayed on cells adherent to the plate after two washes with Krebs-Ringer phosphate buffer containing 20 $\mathrm{mg} / \mathrm{ml} \mathrm{BSA}$ and $1.3 \mathrm{mM} \mathrm{CaCl} \mathrm{CH}_{2}(\mathrm{KRP})$. Cells were incubated for $20 \mathrm{~min}$ at $22^{\circ} \mathrm{C}$ in the presence or absence of insulin in KRP and transport was measured by a 20 -min pulse of 0.2 $\mathrm{mM}$ 2-deoxyglucose $(0.8 \mu \mathrm{Ci} / \mathrm{ml})$. The reaction was terminated by three 3-ml washes with Dulbecco's phosphate-buffered saline at $4^{\circ} \mathrm{C}$. Cells were solubilized in $0.1 \%$ sodium dodecyl sulfate (SDS) and divided into aliquots for liquid scintillation counting and determination of DNA content (26).

\section{RESULTS}

Acute effects of antibody. Both intact Anti-R and Anti-R Fab inhibited the binding of insulin to its receptor (Fig. 1, upper panel). Binding of tracer concentrations of ${ }^{125}$ I-insulin was inhibited by $85 \%$ with $36 \mu \mathrm{g} / \mathrm{ml}$ Anti-R and by $80 \%$ with $40 \mu \mathrm{g} / \mathrm{ml}$ Anti-R Fab. Scatchard analysis revealed that the major effect of both monovalent and intact antibody was to reduce apparent receptor affinity. Thus there was a major decrease in insulin binding to antibody-treated cells at low hormone concentration, but at higher concentrations, insulin binding to antibody-treated cells approached control cells, suggesting that the total number of available receptors remained constant. In terms of number of antibody-combining sites, the titer for inhibition of insulin binding by the Anti-R Fab was only slightly less than that for the intact antibody (Fig. 1, lower panel).

The effect of Anti-R on glucose oxidation by 3T3-L1 cells is shown in Fig. 2 (left). Like insulin, Anti-R stimulated glucose oxidation. Anti-R was slightly more potent in its insulinomimetic action compared with its inhibition of insulin binding. The maximal stimulation of glucose oxidation by Anti-R was observed at 3.5 $\mu \mathrm{g} / \mathrm{ml}$ and ranged between 50 and $85 \%$ of that achieved by insulin. This concentration of Anti-R Fab decreased insulin binding by $40 \%$, consistent with the amount of "spare receptors" seen with these cells (21). Anti-R Fab did not stimulate glucose oxidation at concentrations as high as $350 \mu \mathrm{g} / \mathrm{ml}$. The insulinomimetic activity of Anti-R Fab could be reconstituted by addition of guinea pig anti-human Fab to cells that had been allowed to come to equilibrium with Anti-R Fab (Table I).

Because Anti-R Fab inhibited insulin binding, but had no insulinomimetic activity, its ability to inhibit insulin's action was tested (Fig. 2, right). Anti-R Fab $(20 \mu \mathrm{g} / \mathrm{ml})$ shifted the dose-response curve for insulin 10-fold to the right. This inhibition was overcome by high concentrations of insulin. Thus, Anti-R Fab acts like a competitive inhibitor of insulin action on 3T3-L1 cells.
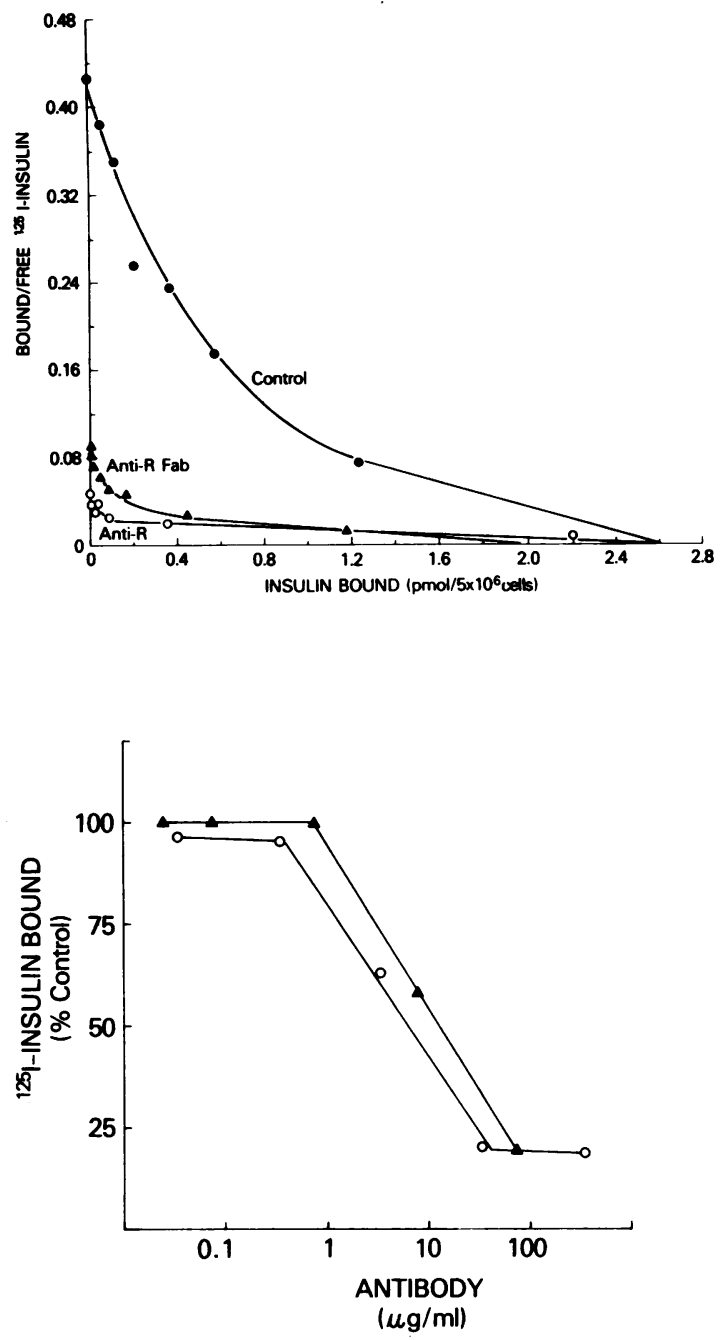

FIGURE 1 Inhibition of insulin binding by antibody against the insulin receptor. 3T3-Ll cells were preincubated in suspension for $30 \mathrm{~min}$ at $37^{\circ} \mathrm{C}$ in the absence or presence of antibody as noted. Cells were then chilled, washed twice in binding buffer at $4^{\circ} \mathrm{C}$, and binding of ${ }^{125} \mathrm{I}$-insulin was determined as described under Methods. Each point represents the mean of at least duplicates which were within $10 \%$ of each other. Top: Scatchard analysis of insulin binding. Additions: , none; O, $35 \mu \mathrm{g} / \mathrm{ml}$ Anti-R; $\Delta, 40 \mu \mathrm{g} / \mathrm{ml}$ Anti-R Fab. Bottom: Titre of inhibition of insulin binding by (O) Anti-R and (A) Anti-R Fab. Control cells bound $3.4 \%$ of tracer insulin.

Prolonged treatment with antibody. When cells were exposed for prolonged periods to Anti-R, the insulinomimetic activity of the antibody disappeared, and glucose oxidation returned to the normal basal rate. This was accompanied by a shift in the insulin dose-response curve to the right and a decrease in the maximal response to insulin (Fig. 3, left). This effect of Anti-R persisted after preparation of the cells for the glucose oxidation assay by repetitive washing. In contrast, after similar prolonged treatment $(24 \mathrm{~h})$ 

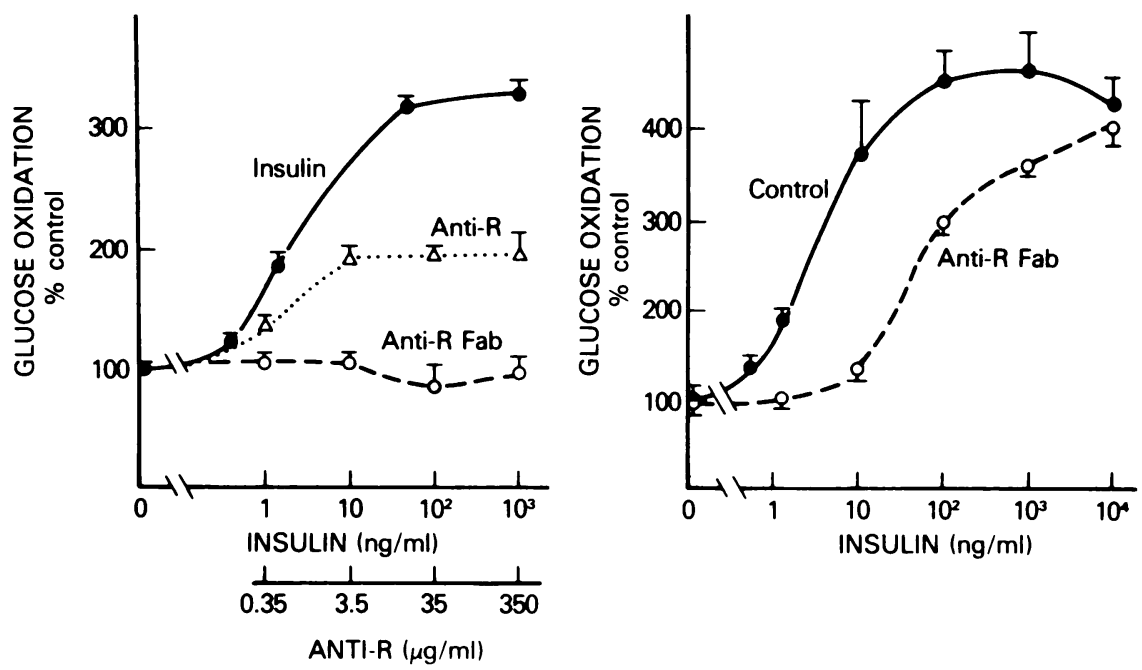

Figure 2 The effects of Anti-R, Anti-R Fab, and insulin on glucose oxidation in 3T3-Ll cells. Glucose oxidation was performed as described under Methods. Insulin or antibody was added directly to the glucose oxidation assay. Error bars represent SEM of duplicate or triplicate determinations. Left: the effects of increasing amounts of insulin (O), Anti-R $(\triangle)$, or Anti-R Fab (O). Basal glucose oxidation for control cells was $7.5 \pm 0.4 \mathrm{nmol} / 10^{6}$ cells per $2 \mathrm{~h}$. Right: Cells were incubated in the absence (O) or the presence (O) of Anti-R Fab $(20 \mu \mathrm{g} / \mathrm{ml})$ and the concentrations of insulin indicated on the abscisşa. Basal glucose oxidation was $4.3 \pm 0.4(\mathrm{SEM}) \mathrm{nmol} / 10^{6}$ cells per $2 \mathrm{~h}$.

with Anti-R Fab followed by washing, there was no inhibition of insulin response (Fig. 3, right). Likewise, no desensitization could be seen when cells were preincubated with Anti-R Fab and assayed for insulinstimulated deoxyglucose uptake; no decrease in the maximal insulin response could be seen (Table II). Pre- incubation with Anti-R Fab followed by incubation with guinea pig Anti-Fab resulted in a small but consistent decrease in insulin stimulation (Table II). Thus, desensitization, like the antibody's insulinomimetic activity, requires bivalence.

Specificity of antibody-induced desensitization.

TABLE I

Reconstitution of Insulinomimetic Activity of Anti-R Fab

Using Guinea Pig Anti-human Fab

\begin{tabular}{|c|c|c|}
\hline \multicolumn{2}{|c|}{ Additions } & \multirow[b]{2}{*}{ Deoxyglucose uptake } \\
\hline First incubation & Second incubation & \\
\hline & & nmol/3.5 m DNA/20 min \\
\hline Buffer & Buffer & $1.27 \pm 0.11$ \\
\hline Buffer & Insulin $(100 \mathrm{ng} / \mathrm{ml})$ & $4.43 \pm 0.27$ \\
\hline Fab $(10 \mu \mathrm{g} / \mathrm{ml})$ & Buffer & $1.12 \pm 0.12$ \\
\hline $\mathrm{Fab}(10 \mu \mathrm{g} / \mathrm{ml})$ & Anti-human Fab 1:1,000 & $1.26 \pm 0.14$ \\
\hline $\mathrm{Fab}(10 \mu \mathrm{g} / \mathrm{ml})$ & Anti-human Fab 1:200 & $1.79 \pm 0.02$ \\
\hline Fab $(10 \mu \mathrm{g} / \mathrm{ml})$ & Anti-human Fab 1:50 & $3.39 \pm 0.09$ \\
\hline Buffer & Anti-human Fab 1:1,000 & $1.59 \pm 0.07$ \\
\hline Buffer & Anti-human Fab 1:200 & $1.22 \pm 0.08$ \\
\hline Buffer & Anti-human Fab 1:50 & $1.32 \pm 0.02$ \\
\hline
\end{tabular}

Cells were prepared for deoxyglucose uptake as described under Methods. The first incubation was in $540 \mu \mathrm{l}$ for $30 \mathrm{~min}$. Then $30 \mu \mathrm{l}$ of the compounds indicated under second incubation was added, without aspiration of the first buffer, to give the final concentrations as designated. The second incubation also lasted $30 \mathrm{~min}$. Deoxyglucose uptake was measured 20 min after addition of a $30-\mu$ l stock solution of $\left[{ }^{14} \mathrm{C}\right]$ deoxyglucose. All incubations were performed at $24^{\circ} \mathrm{C}$. Values represent the mean of triplicates \pm SEM. 


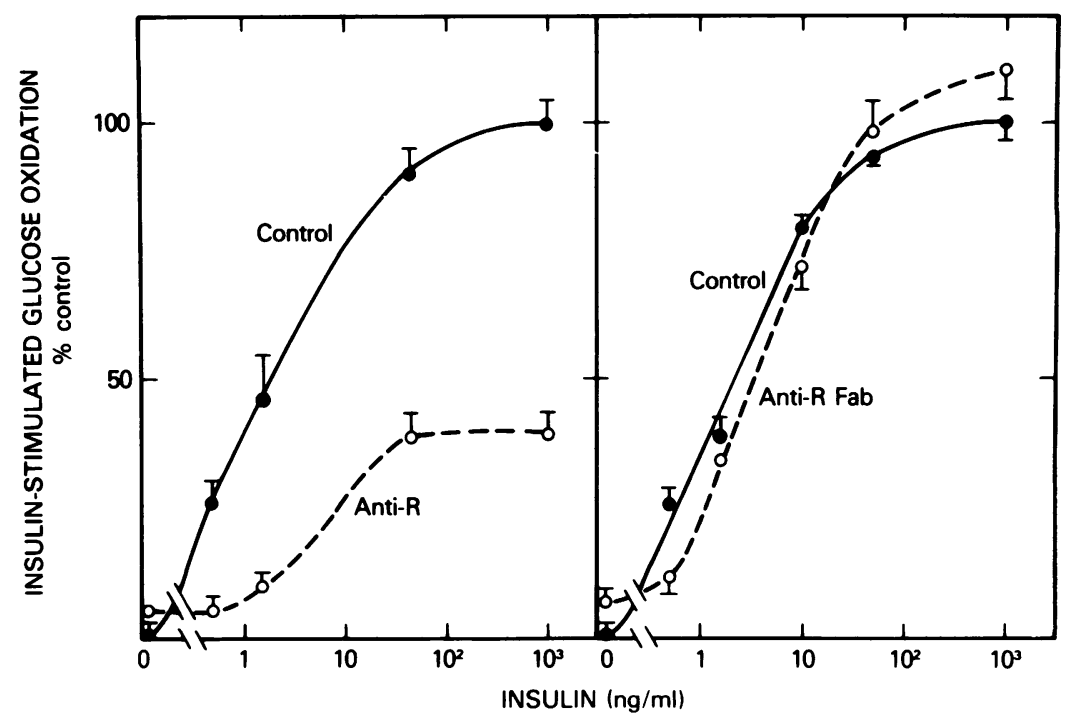

FIGURE 3 The effect of prolonged exposure of 3T3-L1 cells to antireceptor antibody. Cells were exposed to antibody for $24 \mathrm{~h}$ under tissue culture conditions. Subsequently cell suspensions were prepared, and glucose oxidation assayed as described under Methods. Left: Control cells $(O)$ and cells treated with Anti-R $(O)$ at $35 \mu \mathrm{g} / \mathrm{ml}$. Right: Control cells $(O)$ and cells treated with Anti-R Fab (O) at $40 \mu \mathrm{g} / \mathrm{ml}$.

Antibody-induced desensitization appears to be specific for agents that act via the insulin receptor. For example, 3T3-L1 cells that have been desensitized to insulin by prolonged treatment with Anti-R are also resistant to concanavalin $\mathrm{A}$ (Fig. 4), an insulinomimetic agent whose action is thought to be mediated by the insulin receptor (27). The maximal response to concanavalin $\mathrm{A}$ is reduced in desensitized cells (Fig. 4, right). These cells, however, respond normally to vitamin $\mathrm{K}_{5}$ and spermine, two insulinomimetic agents that act independently of the insulin receptor (22).

Medium requirements for desensitization. The insulinomimetic effect of Anti-R was seen when cells were exposed to Anti-R under a wide variety of conditions or media. These included incubation at $15^{\circ}$ or $37^{\circ} \mathrm{C}$ (not shown) and exposure in Dulbecco-Vogt growth medium or simple buffers such as KRP (Fig. 5). Antibody-induced desensitization of 3T3-Ll cells, on

TABLE II

Effect of Guinea Pig Anti-human Fab on Chronic Exposure of 3T3-L1 Cells to Anti-R Fab

\begin{tabular}{|c|c|c|c|}
\hline \multicolumn{2}{|c|}{ Additions } & \multirow[b]{2}{*}{ Transport incubation } & \multirow[b]{2}{*}{ Deoxyglucose uptake } \\
\hline $\begin{array}{c}\text { First } \\
\text { preincubation }\end{array}$ & $\begin{array}{c}\text { Second } \\
\text { preincubation }\end{array}$ & & \\
\hline & & & $n \mathrm{~mol} / 33 \mu \mathrm{g} D N A / 20 \mathrm{~min}$ \\
\hline None & Guinea pig serum & Basal & $2.0 \pm 0.21$ \\
\hline None & Guinea pig serum & Insulin $(10 \mu \mathrm{g} / \mathrm{ml})$ & $9.95 \pm 0.03$ \\
\hline Anti-R Fab & Guinea pig serum & Insulin $(10 \mu \mathrm{g} / \mathrm{ml})$ & $10.32 \pm 0.60^{*}$ \\
\hline Anti-R Fab & Guinea pig anti-Fab & Insulin $(10 \mu \mathrm{g} / \mathrm{ml})$ & $7.43 \pm 0.41 \ddagger$ \\
\hline
\end{tabular}

Cells were incubated in Linbro multi-well plates for $30 \mathrm{~min}$ at $24^{\circ} \mathrm{C}$ in the presence or absence of Anti-R Fab $(10 \mu \mathrm{g} / \mathrm{ml})$ in $900 \mu \mathrm{l}$ of Dulbecco-Vogt medium. Then $90 \mu \mathrm{l}$ of the same medium containing a 1:5 dilution of guinea pig serum or guinea pig anti-human Fab was added, and the cells were incubated for another $30 \mathrm{~min}$ at $24^{\circ} \mathrm{C}$. The plates were then brought to $37^{\circ} \mathrm{C}$ and incubated for $6 \mathrm{~h}$ to allow desensitization to occur. Plates were then processed for deoxyglucose uptake as described under Methods. Data represent the mean \pm SEM of two experiments in duplicate.

* NS from control.

$\ddagger P<0.001$ from control. 


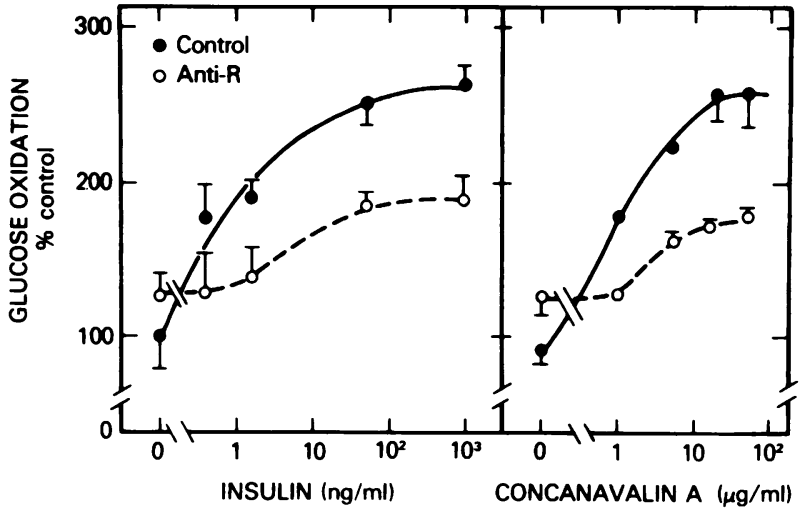

FIGURE 4 The effects of antibody-induced desensitization on the action of insulin and concanavalin A. 3T3-Ll cells were cultured in the absence $(O)$ or presence $(O)$ of Anti-R $(35 \mu \mathrm{g} / \mathrm{ml})$ for $36 \mathrm{~h}$. Suspensions of cells were prepared, and glucose oxidation performed as described under Methods. Left: Insulin. Right: Concanavalin A.

the other hand, was dependent on both temperature and medium composition. In complete Dulbecco-Vogt growth medium, Anti-R stimulated deoxyglucose uptake at $1 \mathrm{~h}$, and desensitization with insulin resistance occurred at $6 \mathrm{~h}$ (Fig. 5 , left). In contrast, if the $6 \mathrm{~h}$ incubation was conducted at $15^{\circ} \mathrm{C}$, no desensitization occurred and the insulinomimetic effect of the antibody persisted (data not shown). However, when cells were exposed at $37^{\circ} \mathrm{C}$ to Anti-R in KRP (rather than DulbeccoVogt medium), the insulinomimetic activity of Anti-R on deoxyglucose uptake (Fig. 5, middle) and glucose oxidation (data not shown) persisted for at least $6 \mathrm{~h}$ without evidence of desensitization. ${ }^{2}$

Similarly, if the same experiment was performed in Dulbecco-Vogt medium prepared without glucose, antibody-induced desensitization did not occur (Fig. $6 \mathrm{~B})$. Addition of glucose $(25 \mathrm{mM})$ to $\mathrm{KRP}$ allowed desensitization to proceed (Fig. 5, right). Pyruvate (Fig. 6C), deoxyglucose (Fig. 6D), glucosamine (not shown), and mannose (not shown) could substitute for glucose in the Dulbecco-Vogt medium, in supporting desensitization, whereas 3-O-methylglucose (Fig. 6E) and galactose (not shown) could not.

Effects of inhibitors of cellular processes. Cycloheximide, an inhibitor of protein synthesis (29), chloroquine, an inhibitor of lysosomal degradation (30), colchicine, an inhibitor of microtubule function (31), and cytochalasin $\mathrm{E}$, an inhibitor of microfilament function (32), were tested for their ability to affect the course of antibody-induced desensitization. ${ }^{3}$ None

\footnotetext{
${ }^{2}$ KRP and Krebs-Ringer bicarbonate contain no glucose. When cells were kept for prolonged periods under these conditions, there was a tendency for basal transport to rise (cf. 28).

${ }^{3}$ Cycloheximide inhibited protein synthesis by $90 \%$ in cells tested in parallel, as measured by the incorporation of ${ }^{3} \mathrm{H}$ -
}

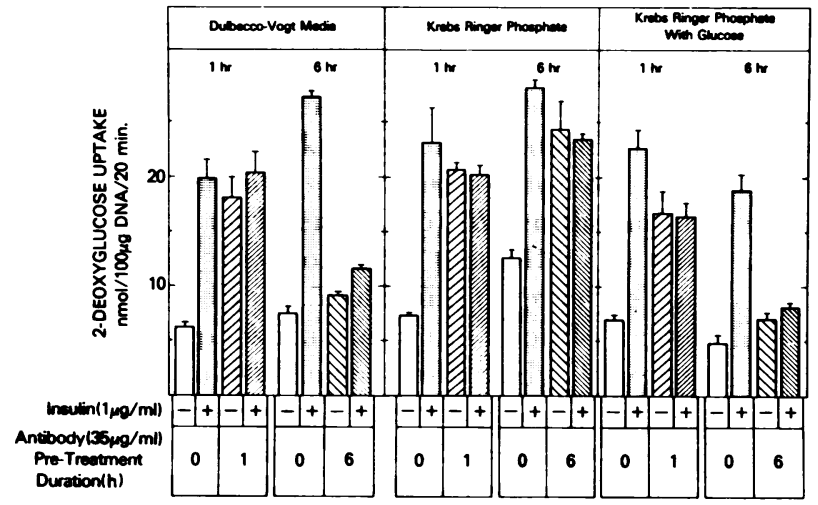

FIGURE 5 Effect of incubation media on antibody-induced desensitization. Cells were rinsed twice in the indicated media and were then incubated at $37^{\circ} \mathrm{C}$ in the presence or absence of Anti-R (35 $\mu \mathrm{g} / \mathrm{ml})$ for the indicated times. Plates were then briefly rinsed and 2-deoxyglucose uptake was assayed for each condition in the presence or absence of insulin $(1 \mu \mathrm{g} / \mathrm{ml})$. Media present during exposure to Anti-R were (left) complete Dulbecco-Vogt modified Eagle's media with $10 \%$ fetal calf serum ( $25 \mathrm{mM}$ glucose); (middle) KrebsRinger phosphate buffer with BSA $(20 \mathrm{mg} / \mathrm{ml})$; and (right) Krebs-Ringer phosphate buffer with BSA $(20 \mathrm{mg} / \mathrm{ml})$ and glucose $(25 \mathrm{mM})$.

of these agents prevented desensitization when added to 3T3-Ll cells before the addition of Anti-R (Fig. 7). As can be seen in the controls for each inhibitor, these agents also had little influence on the ability of insulin to stimulate deoxyglucose uptake. Likewise, the agents had no effect on the insulinomimetic activity of the antibody at $1 \mathrm{~h}$ in 3T3-L1 cells (not shown). Cytochalasin $\mathrm{E}$ at this high concentration inhibited both basal and insulin-stimulated deoxyglucose uptake by almost $50 \%$.

amino acids into protein. Colchicine and cytochalasin $\mathbf{E}$ were used at their maximally tolerated level (higher doses caused detachment of cells during medium changes), which were comparable to those reported for inhibition of microtubules and microfilaments $(31,32)$

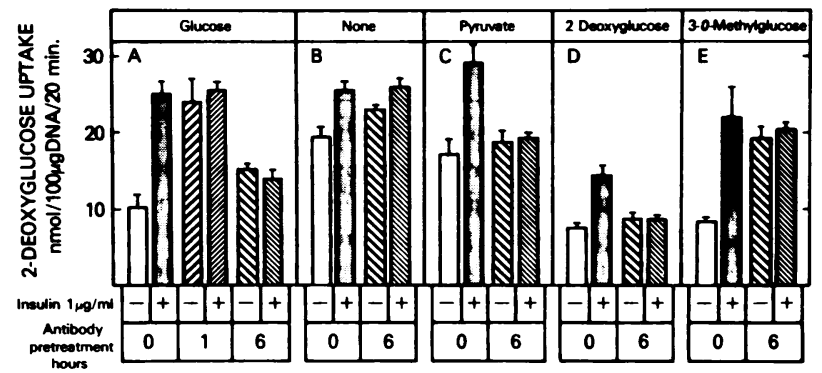

Figure 6 The effects of various compounds on supporting antibody-induced desensitization in glucose-free media. Cells were incubated in glucose-free media prepared as described under Methods and supplemented with (A) $25 \mathrm{mM}$ glucose (B) no additive; (C) $25 \mathrm{mM}$ pyruvate; (D) $25 \mathrm{mM}$ 2-deoxyglucose; or (E) $25 \mathrm{mM} 3-\mathrm{O}$-methylglucose. 


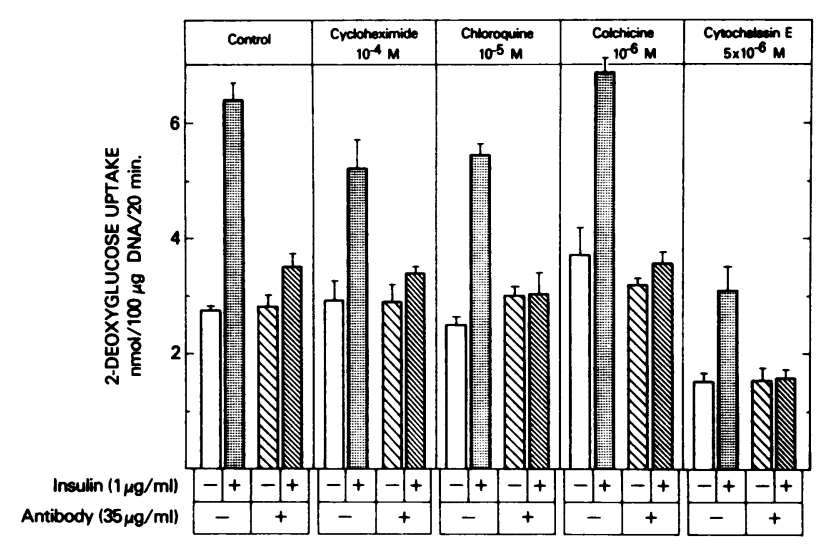

FIGURE 7 The effect of inhibitors of cellular processes on antibody-induced densensitization. Cells were incubated for $6 \mathrm{~h}$ in the presence or absence of Anti-R $(35 \mu \mathrm{g} / \mathrm{ml})$ in Dulbecco-Vogt medium with $10 \%$ fetal calf serum in the presence of no additives or drugs at the concentrations indicated. Plates were then rinsed twice and 2-deoxyglucose uptake measured as described under Methods in the absence or presence of insulin $(1 \mu \mathrm{g} / \mathrm{ml})$.

When desensitized 3T3-L1 cells were placed in fresh medium without Anti- $R$, the response to insulin was recovered within $6 \mathrm{~h}$ (Fig. 8). Addition of chloroquine, cytochalasin $\mathrm{E}$, or colchicine to the media had no effect on the recovery from desensitization (Fig. 8). Cells treated with cycloheximide showed partial recovery from desensitization, indicating that synthesis of new receptor cannot completely account for the recovery from desensitization (Fig. 8).

Using electron microscopic autoradiography, Carpentier et al. (33) have shown that a fraction of Anti-R bound to IM-9 lymphocytes is internalized

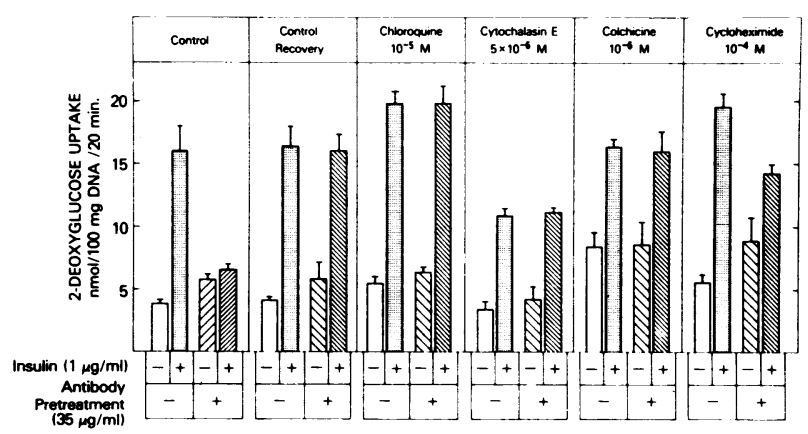

FIGURE 8 Effect of inhibitors of cellular processes on recovery from antibody-induced desensitization. 3T3-Ll cells were treated in the absence or presence of Anti-R $(35 \mu \mathrm{g} / \mathrm{ml})$ for $24 \mathrm{~h}$. Control cells were then incubated for $7 \mathrm{~h}$ more in the same media. Cells treated with inhibitors were exposed for $1 \mathrm{~h}$ to inhibitors at the indicated concentrations. These cells and a second set of control cells (control recovery) were then washed twice with fresh Dulbecco-Vogt medium and incubated for another $6 \mathrm{~h}$ without Anti-R, in media containing the same inhibitors as indicated. Cells were then assayed for 2-deoxyglucose uptake as described under Methods. and localized to the lysosome. It thus seemed possible that the lysosome was involved in desensitization, and therefore the fate of Anti-R bound to cells was studied in more detail. Lysosomal processing of Anti-R also appears to occur in 3T3-Ll cells (Fig. 9). Cells were exposed to ${ }^{125}$ I-labeled Anti-R until equilibrium was reached and then transferred to fresh medium. Dissociation of radioactivity from the cells is characterized by a rapid component that occurs during the first few hours, and a slower component that occurs over 24 (Fig. 9, upper panel) to $48 \mathrm{~h}$ (not shown). Much of the dissociated radioactivity found in the medium with control cells is degraded antibody, as measured by a loss in the precipitability by trichloroacetic acid (Fig. 9, lower panel). Less radioactivity dissociated from cells treated with chloroquine, an inhibitor of lysosomal degradation (30), primarily because of a decrease in the slower component (Fig. 9, upper panel). This decrease was probably the result of inhibition of antibody degradation in the chloroquine-treated cells (Fig. 9, lower panel). Under these conditions, however, chloroquine treatment had no effect on the ability of Anti-R to induce desensitization or on the ability of cells to recover from desensitization (Figs. 7 and 8).

Because dissociation of receptor-bound antibody may account for recovery from desensitization, we compared dissociation of ${ }^{125} \mathrm{I}$-labeled Anti-R and ${ }^{125} \mathrm{I}$ labeled Anti-R Fab. As seen in Fig. 10, Anti-R Fab had a faster dissociation rate than intact Anti-R, indicating that bivalence has a significant effect on the affinity of the antibody for the receptor.

\section{DISCUSSION}

The finding that prolonged treatment of 3T3-L1 cells with antibody against the insulin receptor results in a state of insulin resistance (22) provides us with a model for the disease seen in patients with the syndrome of insulin resistance and acanthosis nigricans type $\mathrm{B}(1,2)$. Although the antibodies effectively inhibit insulin binding, it is not this inhibition per se that is responsible for the desensitization seen in cells treated for prolonged periods with Anti-R. The inhibition of binding occurs rapidly with Anti-R and coincides with its insulinomimetic activity; the loss of the insulinomimetic activity takes several hours, while no further decrease in insulin binding is seen (22). The long-term result is a marked decrease in the maximal response to insulin. All these components make up the process of desensitization.

The fate of the antibody-receptor complex cannot be determined precisely with current methods. Although insulin binding does not seem to change during the process of desensitization, the actual binding in antibody-treated cells is low, and subtle changes in the 

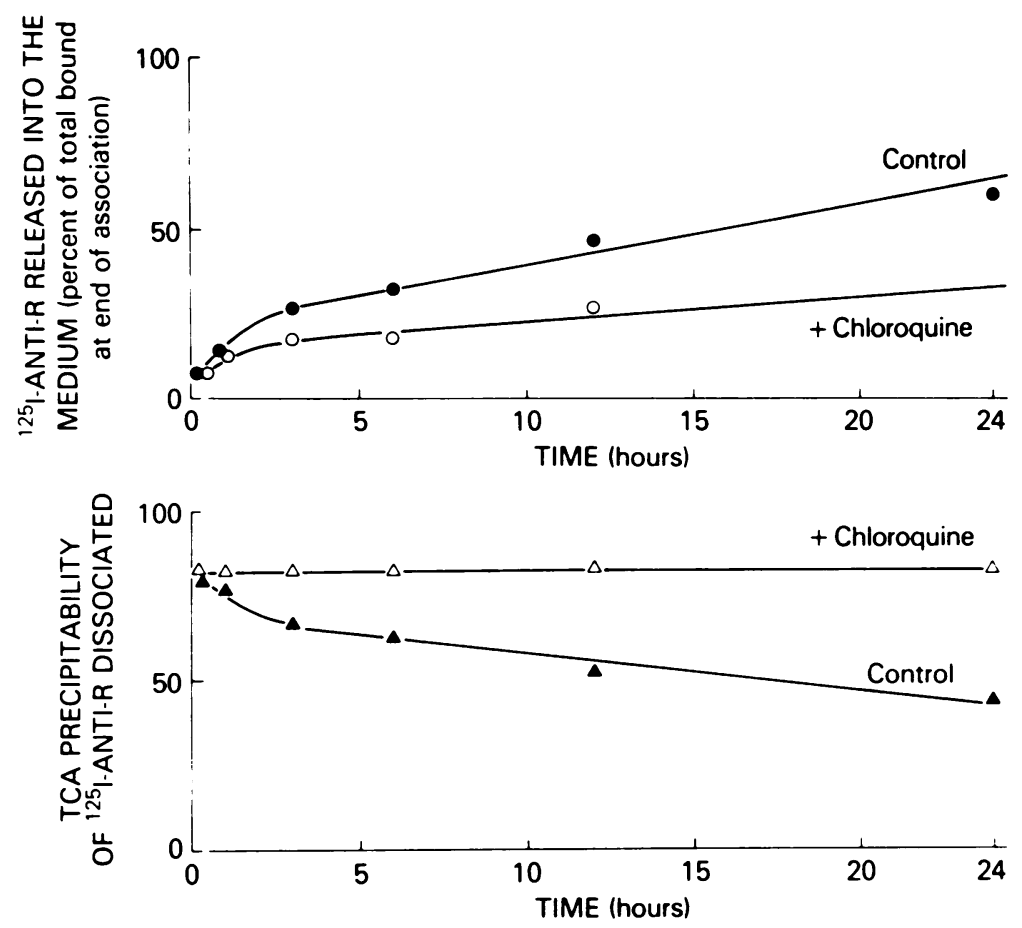

FIGURE 9 The effect of chloroquine on the dissociation and degradation of ${ }^{125}$ I-labeled Anti-R bound to 3T3-Ll cells. ${ }^{125} \mathrm{I}$-labeled Anti-R was prepared as described under Methods. Cells were pretreated for $30 \mathrm{~min}$ at $37^{\circ} \mathrm{C}$ in the presence $(O, \Delta)$ or absence $(\Theta, \Delta)$ of chloroquine $\left(10^{-5} \mathrm{M}\right)$ and then incubated with ${ }^{125} \mathrm{I}$-labeled Anti-R $(10,000 \mathrm{cpm} / \mathrm{ml})$ until equilibrium was reached $(60 \mathrm{~min})$. Cells were then washed twice with fresh media and incubated again in the presence or absence of chloroquine, and the fate of ${ }^{125}$ I was followed. Upper panel: dissociation of label into the medium expressed as percentage of the total ${ }^{125} \mathrm{I}$ bound at the end of the association period. (Control cells bound $7 \%$ and chloroquine-treated cells bound $9 \%$ of ${ }^{125}$ I-Anti-R). Lower panel: Trichloroacetic acid (TCA) precipitability of radioactivity released into media.

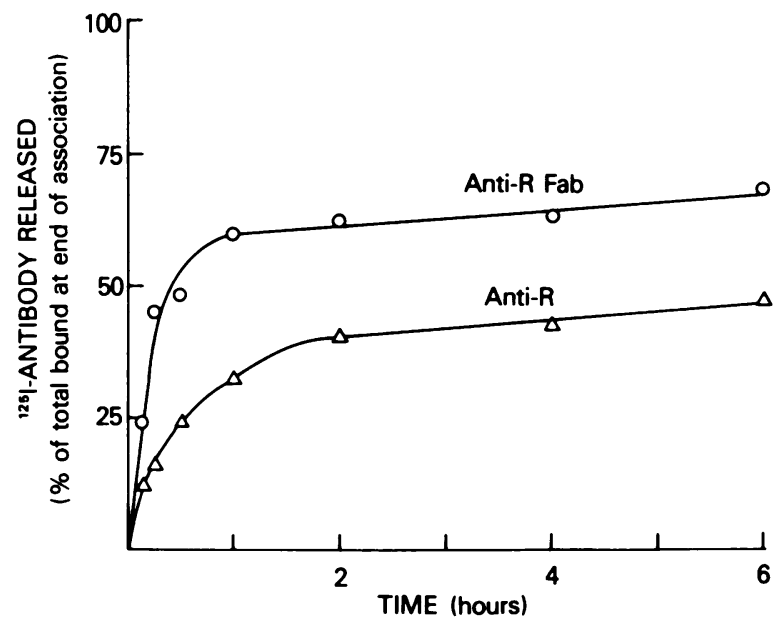

FIGURE 10 Comparison of dissociation of ${ }^{125}$ I-labeled Anti-R and ${ }^{125}$ I-labeled Anti-R Fab from 3T3-L1 cells. ${ }^{125}$ I-labeled Anti-R $(10,000 \mathrm{cpm} / \mathrm{ml})$ and ${ }^{125}$ I-labeled Anti-R Fab $(12,500$ $\mathrm{cpm} / \mathrm{ml}$ ) were incubated with cells for $60 \mathrm{~min}$, and the cells were washed and incubated as in Fig. 9. Cells bound 7\% of ${ }^{125}$ I-labeled Anti-R and $2 \%$ of ${ }^{125}$ I-labeled Anti-R Fab. Recovery in the media of dissociated ${ }^{125}$ I-labeled Anti-R $(\Delta)$ and ${ }^{125}$ I-labeled Anti-R Fab $(O)$ is plotted vs. time.
Scatchard plot would be difficult to detect. There is evidence in vivo that the insulin receptor remains on the membrane surface in the presence of Anti-R. Insulin binding can be restored toward normal on the circulating monocytes isolated from patients with autoantibodies against the insulin receptor by an in vitro acid-wash procedure, which has been shown to remove Anti-R (7). Unfortunately, attempts to remove Anti-R from 3T3-L1 cells by a similar acid wash adversely affect control cells (C. Grunfeld, unpublished observation). Thus we cannot, at this time, determine whether insulin receptors remain on the cell surface during desensitization, although most of the data suggest that this is so. In addition, it should be noted that although exposure of certain cultured cells to insulin has been shown to decrease receptor number $(4,5)$, this does not occur when 3T3-L1 cells are exposed to insulin $(21,27)$. Thus, antibody-induced desensitization is not the same as "down regulation."

The present data indicate that desensitization is an active biological process. Monovalent Fab preparations of Anti-R are able to block insulin binding and inhibit insulin action when acutely added to 3T3-L1 cells, 
but do not reduce the maximal insulin response as seen in cells desensitized with intact Anti-R. In addition, cells treated for prolonged periods with Anti-R Fab do not show persistent inhibition of insulin action, whereas desensitization due to Anti-R does persist under these conditions. Reconstitution of "bivalency" using guinea pig Anti-Fab partially restores the ability of Anti-R Fab to desensitize. Thus desensitization, like the insulinomimetic effects of Anti-R, requires bivalence.

Specificity of desensitization. The specificity of Anti-R for the insulin receptor has been demonstrated in several ways. First, Anti-R inhibits the binding of insulin and insulin's analogues to the insulin receptor, but does not inhibit the binding of other hormones to their receptors $(2,3,23,34)$. Second, Anti-R can immunoprecipitate solubilized insulin receptors, but has no effect on other solubilized receptors (35). Third, Anti-R mimics all of the metabolic effects of insulin that have been tested (8-13). Data presented here further extend this specificity to the process of antibody-induced desensitization. Desensitized cells were still responsive to spermine and vitamin $\mathrm{K}_{5}$, two insulinomimetic agents, which are thought to act independently of the insulin receptor $(36,37)$. Concanavalin $A$, on the other hand, has been shown by multiple criteria to interact with the insulin receptor. It modulates the binding of insulin to its receptor (27), and solubilized insulin receptors adhere to concanavalin A affinity columns (27). In addition, unlike spermine, vitamin $K_{5}$, and hydrogen peroxide, concanavalin $A$ mimics those actions of insulin that are independent of stimulation of glucose transport, i.e., activation of glycogen synthase in the absence of glucose (38) and inhibition of catecholamine-stimulated lipolysis (27). It is therefore not surprising that the insulinlike activity of concanavalin A was blocked in desensitized cells. Antibody-induced desensitization involves a step intimately linked to the insulin receptor.

Requirements for desensitization. The nature of the media in which cells were exposed to Anti-R was found to have a major influence on the development of desensitization. Loss of insulinomimetic activity was not seen when glucose was removed from the medium. However, it is not clear exactly what role glucose plays in desensitization. Glucose is not just required as a source of energy, because 2deoxyglucose and glucosamine, which are not effective energy sources, could also substitute. ${ }^{4}$ 3-O-Methylglucose, which cannot be phosphorylated, did not

\footnotetext{
${ }^{4}$ Deoxyglucose, when added to simple Krebs-Ringer buffer, has been shown to deplete ATP and block insulin action (39); this can be reversed by adding alternative carbon sources (39). For the experiments described in this paper, cells were exposed to Anti-R and deoxyglucose in complete DulbeccoVogt medium with $10 \%$ dialyzed fetal calf serum, lacking only glucose, which provides such alternative carbon sources.
}

substitute for glucose. Phosphorylation is not the only criteria, however, as galactose, which can be phosphorylated, did not substitute for glucose. This pattern, with the exception of pyruvate, is similar to the spectrum of hexose phosphate cofactors, which activate glycogen synthetase (38). Sugar phosphates have also been implicated as cofactors in the control of initiation of protein synthesis (40). It is, of course, possible that these compounds may not play any direct role in antibody-induced desensitization, but may be supportive of other cellular functions which must be intact for desensitization.

In light of the time, temperature, valence, and medium requirements for desensitization, we examined four well-described inhibitors of cellular processes. Although desensitization requires bivalent antibody, which can cause aggregation of receptors on the cell surface, involvement of microtubules or microfilaments is unlikely, as desensitization proceeds in the presence of colchicine or cytochalasin E. Inhibitors of microtubules and microfilaments also have no influence on the biological activity of insulin or the insulinomimetic activity of Anti-R (40). Inhibitors of protein synthesis, which block insulin-induced down regulation in IM-9 lymphocytes (5), likewise have no effect on antibody-induced desensitization. Internalization and lysosomal processing of Anti-R also occurs in 3T3-L1 cells, but it also appears unrelated to desensitization. Lysosomal processing has been implicated in the action of antibodies against the cholinergic receptor in myasthenia gravis (6). Reversal of desensitization is likewise little influenced by these inhibitors. Although Anti-R is degraded by lysosomes in these cells, inhibition of degradation by chloroquine does not block recovery. Likewise, synthesis of new receptors cannot completely account for recovery from desensitization.

In summary, we now have a model for the insulin resistance produced by Anti-R, and although it is not possible at this time to define precisely the mechanism by which this occurs, we have been able to demonstrate certain requirements. It is clear that insulin resistance is not simply the result of Anti-R blockade of insulin binding to its receptor. Occupancy of the receptor by Anti- $R$ is required but not sufficient. As with the insulinomimetic activity of Anti-R, desensitization requires bilvalence. The process also requires time, physiological temperature, and specific components in the medium. The active participation of the cell seems implicated. Further investigation will be required to determine whether the antibody must induce aggregation of receptors or uptake of receptors into the cell to induce desensitization. Preliminary data indicate that both antibody and insulin aggregate on the surface of 3T3-L1 cells and are internalized (Schlessinger, J., C. Grunfeld, E. Van Obberghen, and C. R. Kahn, pre- 
liminary observations). However, because prolonged treatment of 3T3-L1 cells with insulin does not lead to either down regulation or desensitization, other mechanisms must be considered. It is possible that the receptor undergoes a modification in situ, such as phosphorylation, methylation, or acetylation, which changes its ability to initiate a biological response. Such a modification would have to be reversible with dissociation of Anti-R. Clearly, more studies are needed to unravel completely the mechanism of this disease.

\section{ACKNOWLEDGMENTS}

The authors wish to thank Dr. David Jarrett, Dr. George L. King, and Dr. Masato Kasuga for preparations of antibody; Dr. Jesse Roth and Dr. Leonard Harrison for helpful discussions; and Beverly Knight and Violet Katz for secretarial assistance.

\section{REFERENCES}

1. Kahn, C. R., J. S. Flier, R. S. Bar, J. A. Archer, P. Gorden, M. M. Martin, and J. Roth. 1976. The syndromes of insulin resistance and acanthosis nigricans. N. Engl. J. Med. 294: 739-745.

2. Flier, J. S., C. R. Kahn, J. Roth, and R. S. Bar. 1975. Antibodies that impair insulin receptor binding in an unusual diabetic syndrome with severe insulin resistance. Science (Wash. D. C.). 190: 63-65.

3. Flier, J. S., C. R. Kahn, D. B. Jarrett, and J. Roth. 1976. Characterization of antibodies to the insulin receptor: a cause of insulin-resistant diabetes in man. J. Clin. Invest. 58: 1442-1449.

4. Gavin, J. R., III, J. Roth, D. M. Neville, Jr., P. De Meyts, and D. N. Buell. 1974. Insulin dependent regulation of receptor concentrations: a direct demonstration in cell culture. Proc. Natl. Acad. Sci. U. S. A. 71: 84-88.

5. Kahn, C. R., R. S. Bar, F. C. Kosmakos, and J. Roth. 1976. Regulation of insulin receptors by insulin in vivo and in cell culture. Proceedings of the 5th International Congress of Endocrinology. Hamburg, Germany. July 1824. Excerpta Med. Int. Congr. Ser. No. 403. 2: 486-491.

6. Drachman, D. B. 1978. Myasthenia gravis. N. Engl. J Med. 298: 136-142.

7. Muggeo, M. M., C. R. Kahn, R. S. Bar, M. M. Rechler, J. S. Flier, and J. Roth. 1979. The underlying insulin receptor in patients with anti-receptor autoantibodies: demonstration of normal binding and immunologic properties. J. Clin. Endocrinol. Metab. 49: 110-119.

8. Kahn, C. R., K. L. Baird, J. S. Flier, and D. B. Jarrett. 1977. Effects of autoantibodies to the insulin receptor on isolated adipocytes: studies of insulin binding and insulin action. J. Clin. Invest. 60: 1094-1106.

9. LeMarchand-Brustel, Y., P. Gorden, J. S. Flier, C. R. Kahn, and P. Freychet. 1978. Anti-insulin receptor antibodies inhibit insulin binding and stimulate glucose metabolism in skeletal muscle. Diabetologia. 14: 311-317.

10. Kasuga, M., Y. Akanuma, T. Tsushima, K. Suzuk, K. Kosaka, and M. Kibata. 1978. Effects of anti-insulin receptor autoantibody on the metabolism of rat adipocytes. J. Clin. Endocrinol. Metab. 47: 66-77.

11. Kasuga, M., Y. Akanuma, T. Tsushima, Y. Iwamoto, K. Kosaka, M. Kibata, and K. Kawanishi. 1978. Effects of anti-insulin receptor autoantibodies on the metabolism of human adipocytes. Diabetes. 27: 938-945.

12. Lawrence, J. C., J. Larner, C. R. Kahn, and J. Roth. 1978.
Autoantibodies to the insulin receptor activate glycogen synthase in rat adipocytes. Mol. Cell. Biochem. 22: 153-159.

13. Van Obberghen, E., P. M. Spooner, C. R. Kahn, S. S. Chernick, M. M. Garrison, F. A. Karlsson, and C. Grunfeld. 1979. Insulin receptor antibodies elicit a late insulin effect. Nature (Lond.). 280: 500-502.

14. Green, H., and O. Kehinde. 1974. Sublines of mouse 3T3 cells that accumulate lipid. Cell. 1: 113-116.

15. Green, H., and M. Meuth. 1974. An established preadipose cell line and its differentiation in culture. Cell. 3: 127-133.

16. Reed, B. C., S. H. Kaufman, J. C. Mackall, A. K. Student, and M. D. Lane. 1977. Alterations in insulin binding accompanying differentiation of 3T3-Ll pre-adipocytes. Proc. Natl. Acad. Sci. U. S. A. 71: 4876-4880.

17. Rubin, C. S., A. Hirsch, C. Fung, and O. M. Rosen. 1978. Development of hormone receptors and hormone responsiveness in vitro: Insulin receptors and insulin sensitivity in the pre-adipocyte and adipocyte forms of 3T3-Ll cells. J. Biol. Chem. 253: 7570-7578.

18. Mackall, J. C., A. K. Student, S. E. Polakis, and M. D. Lane. 1976. Induction of lipogenesis during differentiation in a "pre-adipocyte cell line." J. Biol. Chem. 251: 6462-6464.

19. Chang, T. H., and S. E. Polakis. 1978. Differentiation of 3T3-Ll fibroblasts to adipocytes. Effect of insulin and indomethacin on the levels of insulin receptors. J. Biol. Chem. 253: 4693-4696.

20. Spooner, P. M., S. S. Chernick, M. M. Garrison, and R. O. Scow. 1979. Insulin regulation of lipoprotein lipase activity and release in 3T3-L1 cells: separation of hormonal effects on hexose metabolism and synthesis of RNA and protein. J. Biol. Chem. 253: 10021-10029.

21. Karlsson, F. A., C. Grunfeld, C. R. Kahn, and J. Roth. 1979. Regulation of insulin receptors and insulin responsiveness in 3T3-L1 fatty fibroblasts. Endocrinology. 104: 1383-1392.

22. Karlsson, F. A., E. Van Obberghen, C. Grunfeld, and C. R. Kahn. 1979. Desensitization of the insulin receptor at an early post-receptor step by prolonged exposure to antireceptor antibody. Proc. Natl. Acad. Sci. U. S. A. 76: 809-813.

23. Jarrett, D. B., J. Roth, C. R. Kahn, and J. S. Flier. 1976. Direct method for detection and characterization of cell surface receptors for insulin by means of ${ }^{125}$ I-labeled autoantibodies against the insulin receptor. Proc. Natl. Acad. Sci. U. S. A. 73: 4115-4119.

24. Roth, J. 1975. Methods for assessing immunologic and biologic properties of hormones. Methods Enzymol. 37: 71-74.

25. Franklin, E. C. 1960. Structural units of human 7S gamma globulins. J. Clin. Invest. 19: 1933-1941.

26. Hinegardner, R. T. 1971. An improved fluorometric assay for DNA. Anal. Biochem. 39: 197-201.

27. Cuatrecasas, P., and G. P. Tell. 1973. Insulin-like activity of concanavalin A and wheat germ agglutinin: direct interactions with insulin receptors. Proc. Natl. Acad. Sci. U. S. A. 70: 485-489.

28. Rosen, O. M., C. J. Smith, C. Fung, and C. S. Rubin. 1978. Development of hormone receptors and hormone responsiveness in vitro: effect of prolonged insulin treatment on hexose uptake in 3T3-L1 adipocytes. J. Biol. Chem. 253: 7579-7583.

29. Pestka, S. 1971. Inhibitors of ribosomal function. Annu. Rev. Microbiol. 25: 487-562.

30. deDuve, C. T., T. DeBarsy, B. Poole, A. Trouet, P. Tulkens, and F. Van Hout. 1974. Lysosomotropic agents. Biochem. Pharmacol. 23: 2495-2531. 
31. Olmsted, J. B., and G. G. Borisy. 1973. Microtubules. Annu. Rev. Biochem. 42: 507-540.

32. Kletzien, R. F., and J. F. Perdue. 1975. Induction of sugar transport in chick embryo fibroblasts by hexose starvation: evidence for transcriptional regulation of transport. J. Biol. Chem. 250: 593-600.

33. Carpentier, J-L., E. Van Obberghen, P. Gorden, and L. Orci. 1979. ${ }^{125} \mathrm{I}$-anti-insulin receptor antibody binding to cultured human lymphocytes: morphological events are similar to the binding of ${ }^{125} \mathrm{I}$-insulin. Diabetes. 28: 345.

34. King, G. L., C. R. Kahn, M. M. Rechler, and S. P. Nissley. 1980. Direct demonstration of separate receptors for growth and metabolic activities of insulin and multiplication-stimulating activity (an insulinlike growth factor) using antibodies to the insulin receptor. J. Clin. Invest. 66: $130-140$.

35. Harrison, L. C., J. S. Flier, J. Roth, F. A. Karlsson, and C. R. Kahn. 1978. Immunoprecipitation of the insulin receptor: a sensitive assay for receptor antibodies and a specific technique for receptor purification. J. Clin. Endocrinol. Metab. 48: 59-65.

36. Czech, M. P., J. C. Lawrence, and W. S. Lynn. 1974. Hexose transport in isolated brown fat cells. A model system for investigating insulin action on membrane transport. J. Biol. Chem. 249: 5421-5427.
37. Livingston, J. M., P. A. Gurny, and D. H. Lockwood. 1977. Insulin-like effects of polyamines in fat cells. Mediation by $\mathrm{H}_{2} \mathrm{O}_{2}$ formation. J. Biol. Chem. 252: 560-562.

38. Lawrence, J. C., and J. Larner. 1978. Activation of glycogen synthase in rat adipocytes by insulin and glucose involves increased glucose transport and phosphorylation. J. Biol. Chem. 253: 2104-2113.

39. Chandramouli, N., M. Milligan, and J. R. Carter, Jr. 1977. Insulin stimulation of glucose transport in adipocytes. An energy dependent process. Biochemistry. 16: $1151-1158$.

40. Ernst, V., D. Levine, and I. M. London. 1978. Evidence that glucose phosphate regulates protein synthesis initiation in reticulocyte lysates. J. Biol. Chem. 253: 71637172.

41. Kahn, C. R., K. L. Baird, D. B. Jarrett, and J. S. Flier. 1978. Direct demonstration that receptor cross-linking or aggregation is important in insulin action. Proc. Natl. Acad. Sci. U. S. A. 75: 4209-4213.

42. Schlessinger, J., Y. Schechter, M. C. Willingham, and I. Pastan. 1978. Direct visualization of binding, aggregation and internalization of insulin and epidermal growth factor on living fibroblastic cells. Proc. Natl. Acad. Sci. U. S. A. 75: 2659-2663. 